\title{
Biochemical Evaluation of Moong Bean (Vigna radiata L.) Characterstics for Nutraceutical Applications
}

\author{
Mamta Rathore, H.G. Prakash, D.P. Singh, Khalil Khan
}

10.18805/IJARe.A-5677

\begin{abstract}
Background: Moong bean (Vigna radiate L.) plays an important role in antioxidant, antimicrobial, antidiabetic, anti inflammatory, antihypertensive and antitumor effects. Mostly beans and legumes cause gas and abdominal bloating in some people but the moong beans are the easy to digest. Soaking the beans in water before cooking and also sprouting them reduces this issue. The high levels of amino acids, oligosaccharides and polyphenols provide high antioxidant levels not only fight tumors and cancer but also protect against DNA damage and cell mutation. The seed of moong bean acts as a nutraceutical because it provides beneficial effects on human health and also helps in the prevention of cardiovascular disease, diabetes, digestive tract diseases, overweight, obesity and cancer etc. The flavonoids vitexin and isovitexin have high free radical scavenging activities which help lower oxidative stress, the cancer causative factor. It is not only lower blood glucose levels, but also reduce total cholesterol levels, triglycerides, plasma C peptides and glucagon levels. Samples of moong bean were collected from Legume Section of the University.

Methods: Through NIRS-2500 evaluated samples of moong bean. It is an instrument through which Near Infrared (NIR) analysis a spectroscopic technique that makes use of the naturally occurring electromagnetic spectrum. This works in the region of the spectrum defined by wavelengths between $700 \mathrm{~nm}$ and $2500 \mathrm{~nm}$. All the cultivars were found to cluster in major four groups on the basis of principal component analysis. The result showed the diversity between nutritional and antinutritional factors in the cultivars that could be further used by plant breeders to develop superior genotypes. The moong bean has lots of advantages which cure the several diseases such as cardiovascular disease, type 2 diabetes, digestive diseases and some cancers.

Result: Histidine amino acid was varied from $6.40 \%$ to $8.81 \%$, arginine amino acid from $2.21 \%$ to $3.87 \%$, valine amino acid from $2.92 \%$ to $4.44 \%$, phenylalanine from $9.73 \%$ to $13.86 \%$, isoleucine from $9.28 \%$ to $10.02 \%$, methionine from $0.09 \%$ to $1.26 \%$, leucine from $6.02 \%$ to $7.65 \%$, tryptophan from $0.30 \%$ to $0.68 \%$, lysine from $2.03 \%$ to $2.22 \%$ and threonine from $4.32 \%$ to $5.56 \%$. The grain color have the direct related to carotenoids and polyphenols. The hardness of the grain is due to fiber amount of the grain. The moisture is related to the properties such as sphericity, porosity, bulk density. Mostly anti-nutrients factors such as phytic acid, tannins, hemagglutinins and polyphenols associated with the grain. The effects of storage and processing on nutrients and food processing properties are needed to enable optimization of processing steps, for better mung bean food quality and process efficiency.

Key words: Antimedicinal, Antioxidants, Protein source, Seed coat, Vitamin.
\end{abstract}

\section{INTRODUCTION}

In leguminosae family or fabaceae includes beans, pea, lentils and groundnut. Protein is a very important nutrient in human life it works as a building block of human body (Butt, 2010). The moong bean seed coat acts as an important food source for human beings. The vegetarian people eats protein rich leafy vegetables and minerals. Commonly known that moong bean or green gram which is a tropical legume in Thailand, India and Pakistan (Oplinger et al.1990) Due to rich in protein and amino acid it suits for food and also supplement for cereal based diets. The lower in saturated fatty acid and also in sodium salt concentration. It is important for cardiac patient and obesity person. This pulse helps to reduce the cholesterol level. It also a good source of thiamin, niacin, vitamin B6, pantothenic acid, iron, magnesium, phosphorus and potassium and a very good source of dietary fiber, vitamin $\mathrm{C}$, vitamin $\mathrm{K}$, riboflavin, folate, copper and manganese (Kishumura, 2013). In India dal and rice combination acts as a staple food. To prepare noodles, soups and bread to select the milled form of the grain. In the India people wants to prefer snacks of moong bean which is spiced and salty in taste. This grain is used as a vegetable
Directorate of Research, C.S. Azad University of Agriculture and Technology, Kanpur-210 203 Uttar Pradesh, India.

Corresponding Author: Mamta Rathore, Directorate of Research, C.S. Azad University of Agriculture and Technology, Kanpur210 203, Uttar Pradesh, India. Email: mamtacsa@gmail.com.

How to cite this article: Rathore, M., Prakash, H.G., Singh, D.P., and Khan, K. (2022). Biochemical Evaluation of Moong Bean (Vigna radiata L.) Characterstics for Nutraceutical Applications. Indian Journal of Agricultural Research. DOI: 10.18805/IJARe.A-5677.

Submitted: 03-09-2020 Accepted: 02-09-2021 Online: 28-01-2022

in the rural area. The whole form of moong bean such as bean stalks, leaves and husks are all used as a livestock feed source (Sefa Dedeh and Stanley, 1979). It improves the soil fertility. It's important features are effected by genetic and environment conditions.

Currently, the world production area of moong bean is about six million hectares per year, out of which $90 \%$ is in Asia, with an average yield of $400 \mathrm{~kg} \cdot \mathrm{ha}^{-1}$.The moong bean has rich dietary quality but the productivity is not as similar as a demand. In human diet it is a source of protein, 
carbohydrate and micronutrients (Mubarak, 2005). It is rich in very desirable amino acid lysine which is mostly deficient in cerearls crop and less amount in methionine amino acid which is a sulphur containing amino acid. The bean consists of high level of antioxidant which is helpful for cleaning the body inside.

\section{Nutritionally rich moong bean}

In comparison to other legumes, such as chickpea (Cicer arietinum), pigeon pea (Cajanus cajan) and lentils (Lens culinaris), moong bean starch is easier to digest. Moong bean also induces less flatulence and is well tolerated by children. This has low amount of phytic acid than pigeon pea, soybean and cereals (Adsule et al, 1986). Phytic acid is commonly found in cereal and legume crops and has a negative impact on iron and zinc bioavailability in plantbased human diets. Moong bean is a rich source of iron so that it is used as baby food (Misiak et al., 2017). In addition, dynamic changes in metabolites during the sprouting process and related biological activities, including antioxidant and health promoting effects, are evidence of its use as a medicine.

1. Prevents heart ailments.

2. Help in to minimize the cholesterol.

3. Provide protein supplement for the children and old age people.

\section{MATERIALS AND METHODS}

\section{Sample preparation}

Moong bean samples from the crops were picked and threshed to remove the peels. The seed samples were kept at a temperature of $25^{\circ} \mathrm{C}$ and a relative humidity of approximately $85 \%$ in an air-conditioned laboratory overnight to attain temperature equilibrium of the seeds before measurement. The samples of these crop were analyzed for their proximate composition. All the work pertaining to this investigation was done in the Laboratories of NIRS in the Directorate of Research, C.S. Azad University of Agriculture and Technology, Kanpur (U.P.). The grain seeds were collected from legume section of Azad university of Agriculture and Technology, Kanpur. After cleaning and grinding the seed samples were determined using NIRS2500 . For analysis we should used three replication for each sample and used the average value for the spectrum calibration. We take $130 \mathrm{gm}$ samples to analyze the sample it works from 400-2500 nm wavelength.

It is an instrument through which Near Infrared (NIR) analysis a spectroscopic technique that makes use of the naturally occurring electromagnetic spectrum. This works in the region of the spectrum defined by wavelengths between $700 \mathrm{~nm}$ and $2500 \mathrm{~nm}$.

It is suited for quantitative determination of the major constituents in most types of food and agricultural products. Principle Near Infrared light is directed into a sample

- The light is modified according to the composition of the sample and this modified light is detected.

- The spectral modifications are converted to information regarding the composition of the sample

- These conversion algorithms are called "calibrations".

\section{Transmission and reflectance}

Infrared spectrum was got by using infrared light which passes through the sample by follow the transmission. The light was reflected by the sample and follow the absorption properties which can be extracted from the reflectance. This spectroscopy can be analyzed the sample by transmittance is good for measuring cheese to obtain a representative measurement throughout the sample. Oplinger et al. (1990) for homogenous samples such as milk powder, reflectance is ideal.

For both methods, the NIR wavelength range is an important consideration. For instance, a Short Wave NIR range (850-1050 $\mathrm{nm}$ ) gives good sample penetration with NIR transmission.

\section{RESULTS AND DISCUSSION}

The biochemical constituents are unevenly distributed in the different parts of the grain. The major chemical components of moong bean dry matter are amino acids, while micronutrients include minerals and vitamins. The minimum and maximum reported values along with calculated average value of each chemical constituent are given for each parameter in the respective tables.

The crude protein content of mung bean shows large variations, which may be due to differences between varieties (Sahay and Singh, 2006).

Proximate composition and amino acid profile Proximate composition plays an important role in determining the overall nutritional quality, as well as the potential use of a food commodity. As shown in Table 1, moong bean were found which are similar to the previous findings obtained.

- In amino acid profile histidine amino acid was varied from $8.41 \%$ to $4.98 \%$ with a mean value of 6.43 . In arginine amino acid was varied from $3.27 \%$ to $1.77 \%$ with a mean value of 2.05. In valine the ranged was varied from $7.64 \%$ to $3.21 \%$ with a mean value of 4.92 .

- The phenylalanine was varied from $14.96 \%$ to $8.00 \%$ with a mean value of 12.41 . The isoleucine was varied from

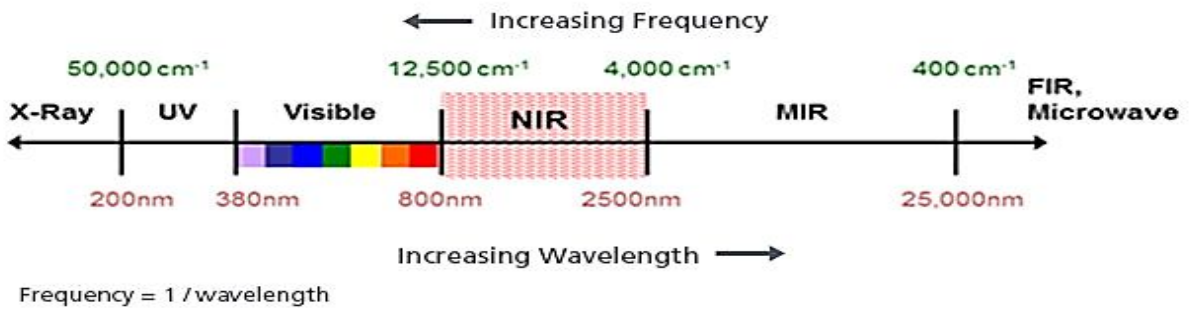


Biochemical Evaluation of Moong Bean (Vigna radiata L.) Characterstics for Nutraceutical Applications

Table 1: To study the amino acid profile of the different variety of the moong bean.

\begin{tabular}{|c|c|c|c|c|c|c|c|c|c|c|}
\hline $\begin{array}{l}\text { Sample } \\
\text { Number }\end{array}$ & $\begin{array}{c}\text { Histidine } \\
(\%)\end{array}$ & $\begin{array}{c}\text { Arginine } \\
(\%)\end{array}$ & $\begin{array}{c}\text { Valine } \\
(\%)\end{array}$ & $\begin{array}{c}\text { Phenylalanine } \\
(\%)\end{array}$ & $\begin{array}{c}\text { Isoleucine } \\
(\%)\end{array}$ & $\begin{array}{c}\text { Methionine } \\
(\%)\end{array}$ & $\begin{array}{c}\text { Leucine } \\
(\%)\end{array}$ & $\begin{array}{c}\text { Tryptophan } \\
(\%)\end{array}$ & $\begin{array}{c}\text { Lysine } \\
(\%)\end{array}$ & $\begin{array}{c}\text { Threonine } \\
(\%)\end{array}$ \\
\hline 2241 Shweta & 4.98 & 1.77 & 6.59 & 8.85 & 10.12 & 0.75 & 8.75 & 0.93 & 2.28 & 4.31 \\
\hline $\mathrm{K}-851$ & 6.58 & 2.66 & 5.23 & 12.66 & 10.22 & 0.23 & 6.89 & 0.77 & 2.21 & 3.97 \\
\hline 2195 Swati & 7.05 & 2.91 & 4.73 & 13.00 & 10.17 & 0.44 & 6.65 & 0.71 & 2.17 & 4.16 \\
\hline T-44 & 6.11 & 2.29 & 5.12 & 9.81 & 9.76 & 0.25 & 8.13 & 0.78 & 2.21 & 4.44 \\
\hline KM-2328 & 8.02 & 3.01 & 3.95 & 14.73 & 10.51 & 0.93 & 5.95 & 0.53 & 2.09 & 4.49 \\
\hline KM -2325 & 1.78 & 1.94 & 7.64 & 10.89 & 8.44 & 1.29 & 5.16 & 1.30 & 2.95 & 0.79 \\
\hline KM-2326 & 6.54 & 2.25 & 4.99 & 12.51 & 10.31 & 0.16 & 6.97 & 0.68 & 2.23 & 4.08 \\
\hline KM-2327 & 5.90 & 1.88 & 5.30 & 11.86 & 10.35 & 0.04 & 7.13 & 0.72 & 2.30 & 4.02 \\
\hline KM-2329 & 6.40 & 2.36 & 4.96 & 11.76 & 10.08 & 0.09 & 7.14 & 0.72 & 2.24 & 4.07 \\
\hline KM-2330 & 6.33 & 2.20 & 5.09 & 12.18 & 10.22 & 0.11 & 7.06 & 0.71 & 2.26 & 3.99 \\
\hline KM-2331 & 7.22 & 2.89 & 4.50 & 13.78 & 10.16 & 0.63 & 6.28 & 0.67 & 2.19 & 3.94 \\
\hline KM-2332 & 7.87 & 3.22 & 3.91 & 14.40 & 10.12 & 0.98 & 5.92 & 0.57 & 2.13 & 4.29 \\
\hline KM-2333 & 6.75 & 2.45 & 4.85 & 12.89 & 10.19 & 0.37 & 6.77 & 0.69 & 2.22 & 4.01 \\
\hline KM-2334 & 7.72 & 3.00 & 4.02 & 14.20 & 10.18 & 0.86 & 6.06 & 0.55 & 2.15 & 4.32 \\
\hline KM-2335 & 5.84 & 2.52 & 5.02 & 10.07 & 9.59 & 0.12 & 7.65 & 0.83 & 2.29 & 3.93 \\
\hline KM-2336 & 7.44 & 3.08 & 4.43 & 13.31 & 10.11 & 0.60 & 6.51 & 0.66 & 2.14 & 4.22 \\
\hline KM-2337 & 8.41 & 3.15 & 3.46 & 14.96 & 10.41 & 1.14 & 5.75 & 0.43 & 2.07 & 4.83 \\
\hline KM-2338 & 5.20 & 1.90 & 5.75 & 10.82 & 10.01 & 0.22 & 7.40 & 0.83 & 2.36 & 3.80 \\
\hline KM-2339 & 6.28 & 2.16 & 5.05 & 12.36 & 10.33 & 0.19 & 6.92 & 0.68 & 2.26 & 4.24 \\
\hline $\mathrm{KM}-2340$ & 6.11 & 2.57 & 5.15 & 12.58 & 9.87 & 0.40 & 6.49 & 0.75 & 2.32 & 3.70 \\
\hline KM-2341 & 5.79 & 2.23 & 5.05 & 10.84 & 9.71 & 0.02 & 7.29 & 0.75 & 2.33 & 3.89 \\
\hline KM-2342 & 7.48 & 2.53 & 4.00 & 12.86 & 10.27 & 0.55 & 6.70 & 0.53 & 2.14 & 4.52 \\
\hline KM-2343 & 5.80 & 2.00 & 5.39 & 11.76 & 10.24 & 0.00 & 7.15 & 0.76 & 2.31 & 3.93 \\
\hline KM-2344 & 6.23 & 2.37 & 5.28 & 12.44 & 10.16 & 0.17 & 6.89 & 0.75 & 2.27 & 3.89 \\
\hline KM-2345 & 7.69 & 3.27 & 4.14 & 14.48 & 10.08 & 0.93 & 5.87 & 0.68 & 2.16 & 3.56 \\
\hline KM-2346 & 7.03 & 2.57 & 4.54 & 12.83 & 10.22 & 0.40 & 6.77 & 0.64 & 2.19 & 4.21 \\
\hline Mean & 6.43 & 2.05 & 4.92 & 12.41 & 9.67 & 0.46 & 6.77 & 0.73 & 2.24 & 3.98 \\
\hline
\end{tabular}

$10.35 \%$ to $8.44 \%$ with a mean value of 9.67 . The methionine was varied from $1.29 \%$ to $0.11 \%$ with a mean value of 0.46. The leusine was varied from $5.16 \%$ to $1.30 \%$ with a mean value of 6.71 . The tryptophan was varied from $0.43 \%$ to $2.95 \%$ with a mean value of 0.73 .The lysine was varied from $2.95 \%$ to $2.07 \%$ with a mean value of 2.24 . The threonine was varied from $4.52 \%$ to $3.79 \%$ with a mean value of 3.98 . The highest values of amino acids in moong bean are reported for phenylalanine $(14.96 \%)$ and isoleucine $(10.41 \%)$.

- Sekhonetal (1980) reported a correlation of protein in moong bean with lysine and threonine, whereas a positive correlation of the amino acids it has been found, that an increase in the methionine content in mung bean is always accompanied by a decrease of the total protein content in moong bean. Isoleucine, leucine, phenylalanine, tyrosine and valine were found to be higher in the globulin fraction of the protein,whereas lysine, methionine, threonine and tryptophan were higher in the albumin fraction (Bhatty,1982) - Mubarak (2005) reported a chemical score of the presence of $76 \%$ amino acids, which was calculated using the $\mathrm{FAO} /$ WHO (1973) reference pattern, whereas Tsou et al. (1979) reported that the chemical score of moong bean proteins is about $32 \%$ of egg protein (FAO, 1970) or $40 \%$ of the FAO provisional pattern. Moong bean grains are adequate in most essential amino acids with the exception of the sulfurcontaining amino acids methionine and cystine, which can be compensated by consuming moong bean in combination with cereals. Cereals are rich in sulfur-containing amino acids and the deûciency of lysine in cereals gets compensated by its presence in moong bean.

\section{CONCLUSION AND SUMMARY}

The histidine amino acid was maximum present in $\mathrm{KM}-2337$ $\mathrm{KM}-2328$ and minimum in KM-2340, KM-2343,T-44. The arginine amino acid was maximum in KM-2337, KM-2332 and minimum in 2241-shweta, KM-2327. The valine was maximum present in 2241-Shweta, KM-2325 and minimum in $\mathrm{KM}-2332, \mathrm{KM}-2337$. The phenylalanine was maximum present in $\mathrm{KM}-2328, \mathrm{KM}-2334$ and minimum in 2241Shweta, T-44. The isoleucine was maximum present in KM2328, KM-2337 and minimum in KM-2325, KM-2335. The methionine was maximum present in KM-2325, KM-2337 and minimum was present in $\mathrm{KM}-2330$ and $\mathrm{KM}-2335$. The leucine was maximally present in 2241-Shweta,T-44 and minimum present in $\mathrm{KM}-2332, \mathrm{KM}-2325$. The tryptophan was highest in KM-2225, 2241-Shweta and minimum present in 
$\mathrm{KM}-2334, \mathrm{KM}-2328$. The lysine was maximally present in $\mathrm{KM}$ 2325, KM-2338 and minimum present in KM-2326, KM-2332. The threonine was maximally present in KM-2328, T-44 and minimally present in $\mathrm{KM}-2325, \mathrm{KM}-2335$.

- On the basis of evaluation the nutritional value of moong bean studied by date. In the research differences are present which is due to several factors such as place of origin, mainly responsible for difference in the properties. According to him moong bean varieties from the Philippines and India and found that Philippine varieties are higher in protein content $(23.4 \%)$ and 1000 seed weight $(59.1 \mathrm{~g})$ than Indian varieties with an average $19.8 \%$ protein and a 1000 grain weight of $27.3 \mathrm{~g}$. On the basis of genetically properties the moong bean has difference in their properties. Physical feature such as color of the grains is a function of genetic makeup of the variety and thus varies among varieties. Difference between the properties of moong bean varieties were also seen. Such as lysine, valine, isoleucine, leucine, phenylalanine and tyrosine than wild varieties in central India.

\section{ACKNOWLEDGEMENT}

This research was conducted at Directorate of research, the Chandra Shekhar Azad University of Agriculture and Technology, Kanpur under NAHEP Center for advanced agriculture Science and Technology on nutritional crops sponsored by ICAR, New Delhi. The financial assistance is duly acknowledged and thanks for Director Research of the University for providing me with the research support.

\section{REFERENCES}

Adsule R. N., Kadam, S.S. and Salunkhe D.K. (1986). Chemistry and Technology of green gram [Vigna radiate (L.) Wilczek[. Crit. Rev. Food Sci. Nut. 25: 73-105.

Babu, C.R., Sharma, S.K., Chatterjee, S.R. and Abrol, Y.P. (1988). Seed protein and amino acid composition of wild $V$. radiata var. sublobata (Fabaceae) and two cultigens, $V$. mungo and $V$. radiata. Economic Botany 42: 54-61.

Bencini, M.C. (1986). Functional properties of drum dried chickpea (Cicer arietinum L.) flour. Journal of Food Science 51: 1518-1526.

Berghout, J. A. M., Boom, R. M. and Van der Goot, A.J. (2015). Understanding the differences in gelling properties between lupin protein isolate and soy protein isolate. Food Hydrocolloids. 43: 465-472.

Beuchart, L.R. (1977). Functional and electrophoretic characteristics of succinylated peanut flour protein. Journal of Agriculture and Food Chemistry. 25: 258261.

Bhadra, S.K., Akhter, M.I. and Quasem, A. (1991). Genetics of seed lustre and joint inheritance of seed-coat colour and seed lustreinmungbean (Vigna radiata L.) Wilczek, Bangladesh J. Bot. 20: 61-64.
Bhatty, R.S. (1982). Albumin proteins of eight edible grain legume species: Electrophoretic patterns and amino acid composition. J. Agric. Food Chem. 30: 620-622.

Blessing, I.A. and Gregory, I.O. (2010). Effect of processing on the proximate composition of the dehulled and undehulled mungbean [Vigna radiata (L.) wilczek] flours. Pakistan Journal of Nutrition. 9(10): 1006-1016.

Boye, J., Zare F. and Pletch, A., Oplinger et al. (2010). Pulse proteins: Processing, characterization, functional properties and applications in food and feed. Food Research International. 43: 414-431.

Butt, M. S. and Batool, R. (2010). Nutritional and functional properties of some promising legumes protein isolates. Pakistan Journal of Nutrition. 9(4): 373-379.

Chitra, U., Vimala, V., Singh, U. and Geervani, P. (1995). Variability in phytic acid content and protein digestibility of grain. Legumes. Plant Foods for Human Nutrition. 35(3): 163-172.

Coffmann, C.W. and Garciaj, V.V. (1977). Functional properties and amino acid content of a protein isolatefrom mung bean flour. International Journal of Food Science and Technology 12(76): 473-484.

Ebert, A.W. and Stanley. (2014). Potential of underutilized traditional vegetables and legume crops to contribute to food and nutritional security, income and more sustainable production systems. Sustainability. 75(6): 319-335.

FAO. (1970). Amino-acid content of foods and biological data on proteins. FAO, Rome.

FAO/WHO.(1973). A review of phytochemistry metabolite changes and medicinal uses of the common food moong bean and its sprouts chemistry cent J.84).

Kishumura, H., (2013). Chemistry and technology of green gram (Vigna radiate L.) Critical Reviews in Food Science and Nutrition, 25(1): 73-105.

Misiak Kamil(2017). Yield and quality of moong bean [Vigna radiata I.R.(Wilczek)] seeds produced in Poland.Bulletin of University of Agricultural Sciences and Veterinary Medicine Cly Napoca Horticultural. 74(2): 149.

Mubarak, A. E. (2005). Nutritional composition and anti nutritional factors of mungbean seeds (Phaseolus aureus) as affected by some home traditional processes. Food Chemistry 89: 489-495.

Oplinger,E.S.,Hardman L.L., Kaminski,A.R.,Comps, S.M and Doll, J.D. (1990). Alternative field crops Manual. Feedipedia Animal Feed resources information System.

Sahay, K.M and Singh, K.K. (2006). Condition and rehulling of pigeon pea and mung beans. Cereal Chemistry. 63(3): 201-207.

Sefa-Dedeh, S. and Stanley, D.W. (1979). The relationship of microstructure of mungbean to water absorption and dehulling properties. Cereal Chemistry. 56(4): 379-386.

Sekhon, M and Dahiya, P.K. (1980). Nutritional Characteristics of Moong Bean Foods. In: Towards redesigning indigenous Moong Bean Foods. 77(1): 428-32.

Tsou, C.S., Hsu, M.S., Tan, S.T. and Park, H.G. (1979). The protein quality of mungbean and its improvement. Acta Hortic. 93: 279-28. 